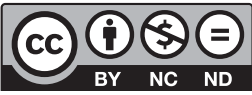

Estudos Teológicos foi licenciado com uma Licença Creative Commons Atribuição - NãoComercial - SemDerivados 3.0 Não Adaptada

http://dx.doi.org/10.22351/et.v59i1.3636

\title{
RELIGIÃo E VIOLÊNCIA NOS LIMITES DA EXPERIÊNCIA HUMANA: UM dí́logo COM EdWARd SCHILlEbEeckX ${ }^{1}$
}

\author{
Religion and violence on the limits of human experience: \\ a dialogue with Edward Schillebeeckx
}

\begin{abstract}
Abdruschin Schaeffer Rocha ${ }^{2}$ Wanderley Pereira da Rosa ${ }^{3}$

Resumo: O presente artigo propõe-se a refletir sobre os limites da relação entre religião e violência tendo como referência principal o teólogo belga Edward Schillebeeckx. Com isso em foco, sugere a violência como algo que não necessariamente tem na religião sua origem, bem como procura mostrar que a religião também não pode ser atrelada automaticamente à violência ou mesmo à não violência. Seu ponto de partida é a conceituação de essencialismo, aplicado tanto à religião como à violência, uma vez que, conforme o ponto de vista dos autores, a categoria de análise essencialista fundamenta uma equivocada e apressada relação entre esses dois entes.
\end{abstract}

Palavras-chave: Religião. Violência. Essencialismo. Edward Schillebeeckx.

Abstract: This article aims to reflect on the limits of the relationship between religion and violence having as main reference the Belgian theologian Edward Schillebeeckx. With this in mind, it suggests violence as something that does not necessarily have its origin in religion, as well as seeking to show that religion can't automatically be linked to violence or even non-violence. Its starting point is the conceptualization of essentialism, applied to both religion and violence, since the category of essentialist analysis grounds a mistaken and hurried relationship between these two entities, according to the authors' point of view.

Keywords: Religion. Violence. Essentialism. Edward Schillebeeckx.

1 O artigo foi recebido em 05 de abril de 2019 e aprovado em 21 de maio de 2019 com base nas avaliações dos pareceristas ad hoc.

2 Doutor em Teologia pela Pontifícia Universidade Católica do Rio de Janeiro. Professor na Faculdade Unida de Vitória, Espírito Santo. Contato: abdo@faculdadeunida.com.br

3 Doutor em Teologia pela Pontifícia Universidade Católica do Rio de Janeiro. Professor e Diretor da Faculdade Unida de Vitória, Espírito Santo. Contato: wanderley@faculdadeunida.com.br 


\section{Introdução}

Estabelecer a relação entre religião e violência não é uma tarefa fácil, sobretudo porque passa inevitavelmente por outra tarefa igualmente difícil: a de estabelecer a natureza da violência e a natureza da religião. O que são, essencialmente, uma e outra? Quais os seus limites? Há alguma relação de causa e efeito ou de qualquer outro tipo? E se há, de que tipo de relação estamos falando?

Há muitas teorias sobre a religião, sobre a violência e sobre a relação entre ambas, que dificilmente conseguiríamos condensar em um artigo. Entretanto, nosso objetivo neste momento delimita nossa abordagem na medida em que busca responder à seguinte pergunta: será a religião essencial e constitutivamente violenta? Há uma parcela significativa de pessoas, incluindo acadêmicos, ativistas, figuras midiáticas ou mesmo pessoas comuns que dão como certa a ideia de que a religião é inerentemente violenta. ${ }^{4} \mathrm{O}$ bordão é recorrente: "A religião foi a causa de todas as grandes guerras da

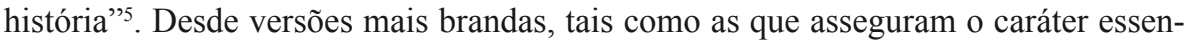
cialmente beligerante da religião - protagonizadas, por exemplo, pelos monoteísmos e seus discursos tidos como intrinsecamente intolerantes ${ }^{6}-$, até versões mais radicais, como a advogada pelo cientista Richard Dawkins, uma espécie de ativista do ateísmo e representante de uma ala mais fundamentalista da ciência, muitos são os posicionamentos que supõem esse caráter violento da religião. ${ }^{7}$ No que respeita à religião, as críticas incluem desde perspectivas que destacam seu aspecto institucional até aquelas que pressupõem que a própria relação imediata com o Absoluto já implicaria a morte da autonomia e da liberdade humanas.

Mas existem também muitas reflexões que buscam em teorias alternativas a origem da violência: será uma questão de animalidade, de racionalidade ou de liberdade e desejo que implicam determinadas escolhas sociais? Ou será que todas essas coisas devem ser consideradas de alguma forma? Em sua primeira parte, este artigo discute os problemas de uma visão essencialista tanto da religião como da violência. Destaca um tipo de essencialismo que se construiu a partir da matriz metafísica como perspectiva que perde de vista a experiência humana, atitude que acaba por compro-

4 Com relação a figuras midiáticas, um bom exemplo é o Documentário RELIGULOUS. Dirigido por Larry Charles; Produção de Bill Maher, Jonah Smith, Palmer West. Apresentação de Bill Maher. Estados Unidos da América: Thousand Words, 2008; no caso de acadêmicos, ver, por exemplo: HITCHENS, Christopher. God is Not Great: how religion poisons everything. First Trade Edition [S.1.]: Atlantic Books, 2007. KIMBALL, C. When religion becomes evil: five warning signs. New York: Harper Collins, 2008. AVALOS, H. Fighting Words: the origins of religious violence. Amherst: Prometheus, 2005. HALL, John R. Religion and Violence: social processes in comparative perspective. In: DILLON, Michele (Ed.). Handbook for the Sociology of Religion. Cambridge University Press, 2003.

5 ARMSTRONG, Karen. Campos de sangue: religião e a história da violência. São Paulo: Companhia das Letras, 2016. p. 11.

6 ARMSTRONG, 2016, p. 12.

7 Cf. DAWKINS, Richard. Deus, um delírio. São Paulo: Cia das Letras, 2007. Um exemplo de sua militância em prol do ateísmo pode ser vista também no Documentário THE ROOT OF ALL EVIL? Dirigido por Russell Barnes. Produzido por Alan Clements. Inglaterra: Channel 3, 2006. 
meter o discernimento da relação entre religião e violência, conforme os autores. $\mathrm{Na}$ segunda parte, o artigo busca discutir a relação religião-violência na perspectiva da experiência humana, destacando a impossibilidade de atrelar à religião tanto a violência como a não violência.

\section{Religião e violência: os problemas de uma visão essencialista}

Partimos do pressuposto de que abordar a relação entre religião e violência a partir de uma abordagem essencialista não apenas implica o risco de um trato simplista, como também pode ela mesma se transformar numa abordagem violenta. Nesta primeira parte, objetiva-se sugerir algumas implicações para uma perspectiva essencialista da relação entre religião e violência e mostrar o quanto tal abordagem desconsidera o humano em toda a sua complexidade.

\section{Religião e violência em perspectiva essencialista}

$\mathrm{O}$ que seria uma religião compreendida de modo essencialista? O que seria pensar o tema da violência numa perspectiva essencialista? Antes de responder a essas perguntas, necessário se faz entender o que pressupõe o conceito de essencialismo e delimitar seu uso aqui neste artigo. De modo geral, pode-se dizer que qualquer teoria que se proponha a explicar a realidade em termos de "essências", independente do modo como sejam tratadas, é uma teoria essencialista. ${ }^{8} \mathrm{O}$ essencialismo remonta aos diversos modos a partir dos quais a questão da essência foi compreendida ao longo da história, pelo menos desde Platão. Desde aquilo que procura indicar uma qualidade do objeto (p. ex., de ser verde e amargo) ou um caráter (como o de ser filósofo ou teólogo) até a compreensão segundo a qual é vista como substância necessária e constitutiva de um ser (como quando se diz que algo não seria o que é não fosse aquilo), a essência adquiriu variadas conotações. ${ }^{9}$

Em certo sentido, Aristóteles é visto como o fundador da teoria da essência ${ }^{10}$, embora tenha em Platão sua principal inspiração. Platão não desenvolveu uma teoria da essência, mas pode-se dizer que seu dualismo, de matiz metafísico, assentou as bases para a construção de um conceito específico de essência, que é esse que o aproxima da ideia de substância enquanto estrutura necessária à existência de um ser. $\mathrm{Ou}$ seja, nesse sentido, a essência enquanto substância diz respeito àquilo que é necessário por oposição ao que é meramente contingente, acidental e acessório. Os dois mundos de Platão - o mundo sensível e o mundo inteligível - também colocaram em compartimentos distintos e estanques essência e aparência, no sentido de que a esta se associa toda a pluralidade e efemeridade do mundo, enquanto àquela liga-se sua

8 Cf. FORNERO, Giovanni. Essencialismo. In: ABBAGNANO, Nicola (Org.). Dicionário de Filosofia. São Paulo: Martins Fontes, 2007. p. 423.

9 Cf. SACCHETTO, Mauro. Essência. In: ABBAGNANO, 2007, p. 417-421.

${ }^{10}$ Cf. ARISTÓTELES. Metafísica. Tradução Joaquim Dornelles. Madri: Gredos, 1987. 
unidade e permanência. Nesse sentido, tocar o mundo em sua aparência não nos daria acesso ao ser-em-si, não nos colocaria frente à sua verdade, apenas nos exporia às sombras de sua impermanência fenomênica.

É no sentido de uma essência substancial e necessária que se poderia pressupor o essencialismo como uma posição a partir da qual se estabelecem algumas separações: propriedades essenciais de acidentais; verdade de descrições; coisa-em-si de fenômenos; fundamento de linguagem etc. Portanto o essencialismo no sentido aqui usado expressa certo dualismo, já que há uma hierarquização que privilegia a essência, a verdade e os fundamentos em detrimento dos acidentes, das descrições e da linguagem arbitrária. Nessa perspectiva, a essência é vista como realidade dotada de uma anterioridade ou de um valor superior ao que se confere à existência. Portanto o pensamento essencialista em algum momento se confunde com o pensamento metafísico, na medida em que a busca pela essência das coisas por oposição às suas aparências projeta um coeficiente de ser que não pode mais ser acessado nas próprias coisas, mas sempre nos remete para além delas, para o "fundo do ser", numa aventura que nos afasta cada vez mais dos fenômenos até definitivamente nos tirar do mundo. Esse caráter "espiritual" do essencialismo, em geral, se contrapõe à experiência terrena e humana. ${ }^{11}$

O que seria, ademais, uma religião essencialista? De modo geral, uma religião que dificilmente reconhece seus vínculos com o mundo e com a história; uma religião que raramente percebe os limites da dimensão linguística e contextual de seus dogmas. Uma religião essencialista transporta seus dogmas e suas declarações de fé para uma dimensão supranatural e supra-histórica, acreditando que sua posição se manterá garantida independentemente do movimento da história e dos limites da linguagem. Isolar a fé das contingências humanas e históricas sustenta, também, o pressuposto de que a Verdade Absoluta pode ser descoberta e acessada em sentido absoluto. Quando consideramos, por exemplo, o cristianismo, sobretudo a eclesiologia católico-protestante, é comum percebermos exageros na apressada distinção entre igreja imaculada e igreja pecadora. A primeira é perfeita e sem ruga e jamais peca; a segunda está sempre sujeita à corrupção e degeneração e supostamente explicaria todos os deslizes ocorridos na história. Embora a ideia de uma igreja perfeita, identificada como a igreja de Cristo, seja interessante como horizonte utópico, em direção à qual pessoas deveriam constantemente se conduzir, corre-se também o perigo de justificar todas as suas mazelas e seduzir grupos a reclamarem pra si a legitimidade de estarem mais perto do que outros dessa igreja perfeita - esse é um dos grandes obstáculos para o diálogo ecumênico. Nesse sentido, o horizonte utópico também pode se transmutar cada vez mais em violência, na medida em que se alinha a discursos baseados num fundacionismo que pressupõe o pleno acesso à verdade absoluta.

11 A tradição pós-metafísica, que se segue à chamada Virada Linguística, rompe com a visão correspondentista e representacional da linguagem, e passa a assumir os elementos contingenciais, as descrições do mundo, os fenômenos etc. Ou seja, nos termos de Platão, isso equivaleria a assumir o mundo sensível e suas implicações como o único lugar possível da "verdade". 
Por outro lado, o que seria pensar o tema da violência numa perspectiva essencialista? Todas as vezes que estamos diante da violência como uma propriedade inerente a algo ou alguém, ou seja, como elemento intrínseco e constitutivo, estamos diante de uma perspectiva essencialista da violência. Para muitos, a religião seria essa instância em relação à qual a violência se constituiria uma propriedade. Quando falamos de algo constitutivo, estamos falando de algo sem o qual aquilo do qual se fala não existiria. Portanto falar da religião como intrínseca e ontologicamente violenta seria equivalente a dizer que sem a violência não haveria religião e sem religião estaríamos livres da violência. A violência, nessa perspectiva, estaria indissociável e irremediavelmente atrelada à religião. Seus adeptos, mesmo os de boa intenção, estariam a serviço de uma violência congênita e inescapável, em discursos e práticas.

Mas como pensar a religião em termos de essências depois de importantes aportes construídos, como, por exemplo, os da história, antropologia e sociologia? Como escapar de uma perspectiva segundo a qual a religião é o que tem sido historicamente? Como não considerar a dimensão humana da religião e o fato de que também resulta de estruturas sociais complexas? Se falamos de uma essência da religião - seja lá o que isso signifique -, o que seria sua instância periférica? Até onde deveríamos ir para achar o "fundo" da religião? São perguntas difíceis de responder e revolvem vínculos metafísicos que nem sempre são considerados. Quanto a isso, deve-se notar que o artífice do chamado pensamento metafísico considera o mundo inteligível - mundo das realidades eternas, mundo da unidade, instância do bem, da verdade e da alma do ponto de vista meramente conceitual. Esse é o conceito de ideia para Platão: um exemplar intuível na multiplicidade. A ideia em Platão pode ser melhor compreendida a partir de um exemplo:

Utilizamo-nos da expressão "humanidade" (exemplar intuível na multiplicidade) para reunir num só conceito os mais de sete bilhões de seres humanos no mundo. Para Platão, portanto, o conceito "humanidade" é mais verdadeiro, puro, real, absoluto... do que cada um dos sete bilhões de pessoas. Enquanto estas estão confinadas ao mundo sensível, o mundo da caverna, aquele faz parte do mundo inteligível, o mundo das realidades absolutas ${ }^{12}$.

Ou seja, a instância das essências não se trata de um mundo real, de seres e de coisas, mas de conceitos puros. Trata-se, portanto, de um mundo desencarnado. E é

12 ROCHA, Abdruschin Schaeffer. O Deus que vem a nós: reflexões hermenêutico-teológicas da revelação desde cima e desde baixo. Horizonte, Belo Horizonte, v. 15, n. 47, p. 974-996, jul./set. 2017. p. 978. As discussões que se seguem a essa perspectiva "ideal" de Platão ganharão contornos mais fortes na disputa entre os escolásticos com relação aos universais. Os nominalistas defendiam a inexistência fática dos universais, argumentando ser um erro buscar referências existenciais em categorias gerais. Ou seja, não existe o ser humano, o brasileiro, a árvore, o animal, apenas pessoas, brasileiros, árvores e animais particulares. Em certo sentido, nessa discussão já estão contemplados alguns elementos que constituirão a chamada Virada Linguística, movimento que criticará vigorosamente o essencialismo de corte metafísico (Cf. GRACIA, Tomas Ibañez. O giro linguístico. In: IÑIGUEZ, Lupicinio (Coord.). Manual de Análise do Discurso em Ciências Sociais. Petrópolis: Vozes, 2005. p. 19-49). 
por isso que a ideia de uma encarnação, tal como preconizada pelo cristianismo, soa tão escandalosa para a filosofia platônica. ${ }^{13}$

$\mathrm{O}$ chamado pensamento metafísico - enquanto matriz visional - se estende para além de Platão e chega à Modernidade. Nesse contexto, abandonam-se a Ideia de Platão, o Cosmo de Aristóteles ou mesmo o Deus do cristianismo - princípios em torno dos quais se consolidou a metafísica antiga e medieval -, e coloca-se o sujeito como fundamento. ${ }^{14}$ Entretanto, a despeito do tom humanista e vanguardista, o humano que se transforma em fundamento não é histórico, não se trata deste ou daquele, afetado pelas contingências socioculturais, mas uma ideia de humano; na verdade, uma abstração. Ou seja, curiosamente o humanismo moderno acaba perdendo de vista os seres humanos reais em favor de uma idealização com pretensões de universalidade. Nesse sentido, a Modernidade também contribui para a construção de um essencialismo que se manifesta como perspectiva metafísico-fundacional, ao perder de vista os vínculos históricos e contingenciais, ou seja, o desde onde o humano pode ser compreendido. Para Joseph Moingt, ao longo da história nem mesmo a teologia ficou imune a isso:

Os teólogos [...] interessaram-se pelos mistérios da eternidade mais que pelas realidades da história, e foi desta maneira que a ideia de Deus terminou por se obscurecer nas especulações da metafísica. A tarefa da teologia hoje - e numerosos teólogos se engajaram nessa via - é reconciliar o em-si de Deus e seu para-nós, sua eternidade e sua presença no tempo. É a condição para reconciliar o pensamento da modernidade com a revelação cristã compreendida sob esta nova luz. É também a condição para fundar sobre Deus mesmo a autonomia e a consistência do mundo ${ }^{15}$.

\section{Violência à revelia da história e da experiência humana}

Uma posição que pressuponha a religião como inerentemente violenta desconsidera os condicionantes históricos, antropológicos, éticos ou políticos, afinal, como vimos anteriormente, no essencialismo se perde o chão da história e da experiência humana. Uma visão essencialista da violência desconsidera, por exemplo, todas as narrativas que sugerem razões histórico-sociais e ético-racionais. A obra de Karen Armstrong, Campos de sangue: religião e a história da violência, é um bom exemplo de resposta a uma visão da violência que ignora os condicionantes históricos e antropológicos. Citando Paul Gilbert, Armstrong menciona os três cérebros humanos que se desenvolveram no processo evolutivo e que coexistem de forma tumultuada: o "velho cérebro", herdado dos répteis e surgido há 500 milhões de anos, destituído de impulso altruísta e programado para a sobrevivência e perpetuação da espécie; o sistema límbico, que surge com os mamíferos há cerca de 120 milhões de anos, que

${ }_{13}$ Cf. HENRY, Michel. Encarnação: uma filosofia da carne. São Paulo: É Realizações, 2013. p. 14-36.

${ }^{14}$ Cf. ROCHA, 2017, p. 978-981.

${ }_{15}$ MOINGT, Joseph. Deus que vem ao homem: do luto à revelação de Deus. São Paulo: Loyola, 2010. v. 1, p. 437. 
motivou comportamentos inéditos, tais como a proteção e criação dos mais novos, a formação de alianças com outros indivíduos e a estima por outras criaturas além deles próprios; e o neocórtex, desenvolvido há cerca de 20 mil anos, durante o Paleolítico, instância do raciocínio e da autoconsciência, responsável pelo afastamento das paixões e dos instintos primitivos. ${ }^{16}$

Embora os seres humanos do Paleolítico tenham alcançado extrema eficiência como assassinos - afinal, dependiam da matança de animais para a sobrevivência -, a empatia desenvolvida no processo evolutivo os inquietava diante da necessidade de sobrevivência. Por isso desenvolveram rituais de purificação no ato da matança de animais, normalmente considerados amigos e patronos. As manifestações religiosas que, segundo antropólogos, aproximam-se dessa violência exercida pelos seres humanos do Paleolítico com relação às suas caças, surgem mais como uma expressão de "solidariedade inefável" ou de senso de comunidade "com a natureza, com o mundo animal e com os outros seres humanos" $" 17$. Ou seja, nem mesmo essa proximidade sustenta a afirmação de que a religião é intrinsecamente violenta. Nesses casos, ao contrário, percebe-se que ela surge para aplacar a violência. ${ }^{18}$

Uma visão essencialista da violência desconsidera essa animalidade inescapável, resultante do processo evolutivo. Com relação à violência da guerra, Armstrong constrói a seguinte definição: "A guerra é um meio de se render à implacabilidade reptiliana, um dos mais fortes impulsos humanos, sem se importar com os cutucões autocríticos do neocórtex". Mas a violência também pode ser um impulso que deriva da busca por sentido, como pode ser visto em alguns soldados que estiveram no campo de batalha, e talvez aqui seja possível um caminho promissor na compreensão de sua relação com a religião, já que essa é uma das principais fontes de sentido. Não se pode ignorar que a violência oferece um propósito, uma causa. ${ }^{19}$ " A violência e coerção [...] estão no cerne da existência social, e na maior parte das culturas antigas essa verdade era expressa por rituais sangrentos de sacrifício animal." ${ }^{20}$ A violência pode

${ }^{16}$ GILBERT, Paul apud ARMSTRONG, 2016, p. 15ss.

17 ARMSTRONG, 2016, p. 16-17.

${ }^{18}$ Essa relação antropológica entre religião e violência também pode ser vista na "teoria do desejo mimético" e no conceito de "bode expiatório" de René Girard. Ver as seguintes obras: GIRARD, René. A violência e o sagrado. São Paulo: Paz e Terra, 1990. GIRARD, René. Eu via Satanás cair como um relâmpago. São Paulo: Paz e Terra, 2012. GIRARD, René. A rota antiga dos homens perversos. São Paulo: Paulus, 2009. GIRARD, René. O bode expiatório. São Paulo: Paulus, 2004. GIRARD, René. O sacrificicio. São Paulo: É Realizações, 2011. Para uma visão sintética desses conceitos, ver ROCHA, Abdruschin Schaeffer; OLIVEIRA, David Mesquiati de. Teologia da missão e violência: superar a violência interna e agir energicamente contra a injustiça. Pistis e Praxis, Curitiba, v. 10, n. 1, p. 144-166, jan./abr. 2018.

${ }^{19} \mathrm{Na}$ sequência à argumentação de Armstrong sobre o propósito conferido pela guerra, surge a ideia de que a violência também encontra sua plausibilidade nos limites da linguagem: apesar do estratagema evolucionário que ajudou nossa espécie a sobreviver - que é o tabu contra matar pessoas de nossa própria espécie -, continuamos a lutar e aí apelamos a definições do que seja a violência, do que seja o humano; exageramos as diferenças do outro e desenvolvemos narrativas que nos convençam de que aqueles contra os quais somos violentos, na verdade, não são humanos, mas monstruosos, o que prontamente justificaria a violência (Cf. ARMSTRONG, 2016, p. 19-20. Ver também LOSURDO, Domenico. A não violência: uma história fora do mito. Rio de Janeiro: Revan, 2012).

${ }^{20}$ ARMSTRONG, 2016, p. 41. 
ser relacionada, desde os primórdios, a disputas por terra, ao surgimento paulatino de uma aristocracia dominante que considerava o trabalho uma subserviência, uma demonstração de inferioridade, incompatível com a vida nobre. O poema de Gilgamesh, por exemplo, indica que jovens já se irritavam com a banalidade da vida civil e procuravam o sentido para suas vidas na guerra. ${ }^{21}$

$\mathrm{Na}$ Suméria, é bem provável que tenham sido os pastores das regiões montanhosas em torno do Crescente Fértil os responsáveis por levar a guerra. A riqueza das cidades pode ter seduzido esses pastores, levando-os a desenvolver a arte do ataque-surpresa. Reis da Suméria paulatinamente vão se transformando de sacerdotes especializados em astronomia e rituais em guerreiros à semelhança de Gilgamesh, pois vão percebendo que a guerra era uma inestimável fonte de receita e força de trabalho. A guerra fornecia recursos mais rápidos e maiores do que as colheitas. ${ }^{22}$

O processo evolutivo do ser humano mostra-nos que a violência está relacionada, de alguma forma, com sua animalidade. Mas como se pode perceber, o desenvolvimento de um cérebro capaz de afastá-lo das paixões mais primitivas não o eximiu da possibilidade de violência. Há uma dimensão animal da violência, mas, sem dúvida, ela também é o resultado de projetos que nascem na liberdade, na autonomia e na racionalidade de indivíduos e grupos. A história da metafísica não pode ser entendida senão como um projeto de racionalidade violenta, que se travestiu até mesmo em ideais que nortearam a Modernidade Ocidental. ${ }^{23}$ Este tripé instaurado pela Modernidade - liberdade, autonomia e racionalidade ${ }^{24}$-, amplificou o potencial ético humano, a despeito de curiosamente o projeto moderno ter sido vendido como uma espécie de superação da religião ou como a reinterpretação dessa nos limites da razão ilustrada. É claro que a religião não sucumbiu ante o secularismo amplamente difundido, mas é certo que visões de mundo contrárias à religião encontraram na Modernidade terreno fértil. Entretanto, também é na perspectiva da ética que se seguiu à Ilustração que se verifica a violência amparada numa liberdade deformada, numa autonomia irresponsável e na corrupção de nossa razão e interioridade.

É também numa perspectiva ética que Hannah Arendt desenvolve sua compreensão da violência. Para ela, a violência sempre precisa de implementos e é por isso que a revolução da tecnologia, responsável pela fabricação de instrumentos, foi amplamente notada na guerra. Em sua opinião, a substância da ação violenta se deixa reger pela categoria meio-fim. Quando aplicada aos negócios humanos, a principal característica da ação violenta tem sido a de que o fim corre o risco de "ser suplantado pelos meios que ele justifica e que são necessários para alcançá-los" ${ }^{25}$. Arendt distingue o fim da ação humana dos produtos finais da fabricação, que podem conferir

21 ANÔNIMO. A Epopeia de Gilgamesh. São Paulo: Martins Fontes, 2011.

22 ARMSTRONG, 2016, p. 44-45.

23 Ver, por exemplo, GIRARD, René; VATTIMO, Gianni. Cristianismo e relativismo: verdade ou fé frágil? Aparecida: Santuário, 2010. VATTIMO, Gianni. Creer que se cree. Buenos Aires: Paidós, 1996. VATTIMO, Gianni. La sociedade transparente. Barcelona: Paidós Ibérica, 1990.

${ }^{24}$ Cf. HABERMAS, Jürgen. El discurso filosófico de la modernidad. Madri: Taurus, 1989.

25 ARENDT, Hanna. Sobre a violência. 3. ed. Rio de Janeiro: Relume Dumará, 2001. p. 14. 
alguma noção de fim. Para ela, diferentemente desses produtos finais, o fim da ação humana nunca pode ser previsto de modo confiável, e é por isso que "os meios utilizados para alcançar os objetivos políticos são muito frequentemente de maior relevância para o mundo futuro do que os objetivos pretendidos" ${ }^{26}$. Ou seja, os objetivos finais podem ser alterados e redefinidos, podem se perder, podem parecer pequenos em relação ao que pareciam no início, e isso pode finalmente tornar os meios os verdadeiros protagonistas dessa relação. Isso significa que o resultado das ações humanas não se deixa controlar por seus atores.

\section{Religião e violência nos limites do humano}

Como se viu anteriormente há muitas alternativas à compreensão essencialista da relação entre religião e violência. Neste momento, gostaríamos de destacar uma dessas possibilidades: vê-la do ponto de vista antropológico, especialmente na perspectiva da realização humana. Um autor pode aqui nos ajudar: o teólogo dominicano belga Edward Schillebeeckx. Sua perspectiva nos colocará em melhores condições para responder às seguintes perguntas: há uma relação constitutiva entre religião e violência? E quanto à libertação (não violência) - ela se liga constitutivamente à religião?

\section{O descompasso entre religião e violência}

Edward Schillebeeckx nasce às vésperas da Primeira Guerra Mundial (1914) e escreve sua derradeira obra no contexto da queda do Muro de Berlim (1989), no fim da chamada Guerra Fria. A trajetória intelectual de Schillebeeckx liga-se diretamente aos eventos que se dão nesse contexto, no qual se percebe o descompasso entre os significativos incrementos no campo cultural e os (ainda) tímidos vestígios de abertura no âmbito da igreja. Sua busca o guiará em direção a algumas filosofias que o influenciarão, tais como a fenomenologia, o existencialismo e o personalismo. O teólogo dominicano será exposto ao confronto apaixonado entre a cultura francesa, assimilada em sua breve vivência parisiense, e o engagement do mundo, que servirá de matéria-prima capaz de possibilitar os novos movimentos democráticos que se seguem ao pós-guerra. Sua experiência na França, embora curta, influenciará indelevelmente sua mentalidade teológica. ${ }^{27}$ A perspectiva de um engagement do mundo será fundamental ao teólogo dominicano, afinal, lhe capacitará a somar esforços na busca pelo encurtamento da distância que separava a Igreja Católica Romana do mundo moderno, de modo a garantir a relevância da fé em termos objetivos. A formação filosófica, herdada de seu mestre De Petter, além da metodologia histórico-teológica assimilada no Le Saulchoir, palco de sua defesa de doutorado realizada em 1951, influenciarão grandemente a hermenêutica de Schillebeeckx, que se nutrirá tanto do

\footnotetext{
26 ARENDT, 2001, p. 14.

${ }_{27}$ Cf. BRAMBILLA, Franco Giulio. Edward Schillebeeckx. São Paulo: Loyola, 2006. p. 11-12.
} 
apelo transcendental, derivado do contato imediato e pessoal com Deus, como das mediações antropológicas da corporeidade-mundanidade e da intersubjetividade. ${ }^{28}$

[...] para o teólogo dominicano a antropologia é condição de possibilidade da revelação. Sua perspectiva transcendental não prescinde, de forma alguma, da vivência, antes se constitui na explicitação daquilo que se encontra de modo irreflexivo e aleatório na experiência humana. Na verdade, Schillebeeckx se destaca como um teólogo que abordou ampla e originalmente a relação entre fé e experiência, problemática enfrentada por praticamente todas as teologias do século XX que se confrontaram com a redescoberta da subjetividade feita pelo pensamento moderno, tanto no mundo católico quanto protestante-evangélico. Sua reflexão em torno da teologia como compreensão da experiência cristã deriva de sua segunda fase, que se inicia após o Concílio Vaticano II, especialmente depois de $1967 .{ }^{29}$

Em artigo publicado em 1997, Schillebeeckx defende a ideia de que a violência não é um elemento inerente à essência da religião. Para o teólogo belga, a religião é a forma cultural de uma salvação-a-partir-de-Deus, e enquanto tal diz respeito ao modo como concretamente essa religião se nos apresenta. ${ }^{30}$ Trata-se aqui da religião institucional, mediatizada, expressa concretamente na história. Percebe-se que o recorte de Schillebeeckx - que por ora deixa de lado a religião enquanto experiência epifânica, imediata, selvagem, pré-racional - é fundamental para se compreender o modo como ele percebe a relação entre religião e violência. Para ele, as pessoas são seres culturais, sujeitos da religião, e a fé cristã que é assimilada na vida inevitavelmente é modelada e mediada pela cultura concreta, que também é o lugar dentro do qual essa fé é praticada concretamente pelas pessoas. É a partir dessa mediação sociocultural que é possível uma aproximação entre religião e violência. Ou seja, somente como componente sociológico da sociedade cultural, a religião pode promover a violência, já que a cultura condiciona essa religião que se expressa concreta e institucionalmente. O desejo de superioridade, por exemplo - que enquanto componente sociocultural caracteriza os seres humanos desde há muito e de cujo mal o cristianismo nem sempre foi uma exceção -, constitui empecilho ao convívio pacífico das religiões e ao estabelecimento de uma cultura que seja digna dos seres humanos. ${ }^{31}$

$\mathrm{Na}$ tentativa de mostrar que não se trata de um assunto de fácil discernimento, Schillebeeckx cita Tomás de Aquino (que poderia muito bem ser caracterizado como um homem manso) e sua legitimação teológica da violência. À semelhança de Aquino, para muitos a relação com o Absoluto era uma questão de vida ou morte, ou seja, não deveria ser considerada de maneira frouxa, afinal, para o crente, "nada do que é

${ }^{28}$ Cf. BRAMBILLA, 2006, p. 34.

29 ROCHA, Abdruschin Schaeffer. Revelação e vulnerabilidade: caminhos para uma hermenêutica da revelação a partir da presença-ausência. 2015. Tese (Doutorado) - Departamento de Teologia, Pontifícia Universidade Católica do Rio de Janeiro, Rio de Janeiro, 2015. p. 156.

30 SCHILLEBEECKX, Edward. Religião e violência. Concilium, Petrópolis, v. 272, n. 4, p. 168-185, 1997. p. 168.

31 SCHILLEBEECKX, 1997, p. 168-169. 
humano pode subtrair-se a este laço de criação com o Absoluto" "32. Ademais, visto a partir de nossa perspectiva, toda suposta relação "direta" com o divino, na verdade, é mediatizada, seja pela cultura, pelas relações sociais ou mesmo pela linguagem. No entanto, há mediações boas e mediações ruins. A violência, para Schillebeeckx, obviamente se trata de uma mediação ruim, todavia possível à religião. A inevitabilidade da mediação, portanto, torna frágil o pressuposto de que há uma relação constitutiva e essencialista entre religião e violência. Falsas alianças que se constroem a partir de mediações equivocadas têm o potencial de estimular pessoas à violência religiosa, em nome de uma suposta relação com o Absoluto. Embora não se possa estabelecer a religião, em si, como libertadora ou opressora - sobretudo quando se percebe a dificuldade teórica de se fundamentar a ideia de uma religião em si -, é possível falar de uma religião libertadora ou opressora na medida de sua relação com a violência, já que esta seria uma excrecência daquela. Portanto, para o teólogo dominicano, toda violência em nome da religião é má, embora a religião não seja essencialmente má. ${ }^{33}$

Schillebeeckx deseja estabelecer a tese de que os fundamentos que supostamente sustentariam a ideia de violência religiosa são falsos, afinal, não são nem de origem religiosa nem cristã. A pretensão de qualquer religião de se estabelecer como única e verdadeira - o primeiro fundamento falso na opinião de Schillebeeckx - nega a legitimidade de outras religiões, portanto é violenta. ${ }^{34}$ Mas não se pode negar que sua origem seja humana e como tal esteja sujeita a uma "hermenêutica da existência" - que se sustenta sobre o pressuposto de justiça a todos os seres humanos -, já que a dignidade humana se constitui na base direta do ethos humano, mesmo que na região dessa autonomia humana sejam encontrados vestígios de transcendência religiosa.

O segundo falso fundamento tem a ver com a suposição equivocada "de que a relação religiosa com o Absoluto implica numa conexão direta com a ordem sócio-política criada pelos homens" ${ }^{35}$. Ou seja, trata-se aqui da velha artimanha de se assumir determinada moral como a expressão exata da vontade de Deus que, segundo Schillebeeckx, deriva de uma aliança da religião cristã com o antigo conceito da "religio". A violência, portanto, surge da atitude de se estabelecer uma conexão direta entre o Absoluto e determinada ordem sociopolítica terrena. ${ }^{36}$ Tal conexão pode se manifestar numa religião do Estado ou mesmo no mero reconhecimento estatal de

32 SCHILLEBEECKX, 1997, p. 172.

33 SCHILLEBEECKX, 1997, p. 172.

${ }^{34}$ A posição de Schillebeeckx coloca uma nova questão: o cristianismo, enquanto religião monoteísta, não necessária e inevitavelmente está fadada a ser violenta em seu discurso, afinal, a crença num único Deus (que é o modo como se expressa a revelação do divino no caso dos monoteísmos) não implica, necessariamente, a pretensão de se estabelecer como a única verdadeira religião, sobretudo, quando se concebe a religião e suas possibilidades na perspectiva da "recepção". Ao contrário de uma visão essencialista, numa perspectiva de "recepção" contenta-se com o modo como a divindade chega a alguém ou a determinado grupo, sobretudo quando se tem consciência da importância e do potencial de determinação do próprio locus. Quanto à revelação nessa perspectiva, ver ROCHA, 2017.

${ }^{35}$ SCHILLEBEECKX, 1997, p. 175.

${ }^{36}$ Como, por exemplo, no caso daqueles que enxergam o conflito entre palestinos e israelenses sob uma perspectiva teológico-religiosa, concedendo a estes últimos o crédito de propriedade da região, posto que isso teria sido determinado pelo próprio Deus. 
alguma "religião oficial". Pode também se manifestar numa espécie de religiosidade que paulatinamente vai moldando as consciências a ponto de mobilizar multidões em torno de um projeto político decidido nas urnas. ${ }^{37}$ Esse falso fundamento é tão condenável quanto o primeiro, mas, por razões humanas e éticas, já que se constitui numa violação dos direitos humanos.

Schillebeeckx supõe uma reciprocidade entre teologia e antropologia e, embora advogue uma perspectiva transcendental da revelação, não o faz ao prejuízo da experiência humana. Para ele, ao contrário, a revelação se constitui numa experiência expressa com palavras ${ }^{38}$; trata-se também de ação salvífica de Deus na medida em que é experimentada e expressa pelo ser humano. ${ }^{39}$

Há de se pressupor, portanto, uma inseparabilidade e, ao mesmo tempo, uma diferença - e essa é a tese antropológica fundamental do teólogo dominicano - na relação absoluta com Deus e nossas relações com o mundo e com outros semelhantes. ${ }^{40}$ Suas teses com respeito ao ser humano enquanto "espírito no mundo", intersubjetividade e corporeidade sustentam sua radical formulação: "extra mundum nulla salus" ("fora do mundo não há salvação"), uma tentativa de superação da tese exclusivista "extra ecclesiam nulla salus" ("fora da igreja não há salvação"), reafirmada no Concílio de Ferrara-Florença, em 1442. ${ }^{41}$ Para que se extraia das reflexões de Schillebeeckx algo que possa nos auxiliar a compreender melhor a relação entre religião e violência, deve-se manter à vista sua perspectiva com respeito à natureza da revelação: superar o horizonte metafísico em busca de um conceito de revelação que se dê na própria história humana.

Para Schillebeeckx, portanto, desde que a religião deve ser vista a partir do modo como se expressa social e culturalmente, não poderia haver nenhuma conexão interna e constitutiva entre religião e violência, embora na prática seja possível à religião aproximar-se da violência na medida em que busca sua pretensão de verdade.

37 Nos últimos anos, essa tendência em se assumir uma moral "cristã" como a expressão exata da vontade de Deus, que supostamente poderia se materializar em determinada ordem sociopolítica, tem se exacerbado no Brasil. Isso ficou particularmente mais evidente nas eleições de 2018.

38 Schillebeeckx se distancia do antigo referencial teórico que marca sua primeira fase, o tomismo acadêmico, e inicia uma nova fase, marcada pelo diálogo com as novas hermenêuticas e, mais diretamente, com a experiência do ser humano secular contemporâneo, numa tentativa de compreender mais plenamente a experiência cristã, concreta e contemporânea. (Ver GIBELLINI, Rosino. A teologia do século XX. São Paulo: Loyola, 2002. p. 323-325.)

39 Cf. SCHILLEBEECKX, Edward. Cristo y los cristianos: gracia y liberación. Madrid: Cristiandad, 1982. p. 38.

40 A inseparabilidade indica que não se pode sustentar uma relação com Deus que seja abstraída da trama histórica da própria existência, já que Deus é acessado apenas por meio da mediação da vivência humana. A diferença, por outro lado, diz respeito à maneira como a mediação das relações relativas em face à absoluta é apreendida pelo pensamento reflexivo, já que discerne a distinção entre o aspecto que funda e constitui a relação absoluta e aquele que revela e exprime as dimensões intramundanas do ser humano (Cf. BRAMBILLA, 2006, p. 37-39).

${ }^{41}$ Cf. SCHILLEBEECKX, Edward. História humana: revelação de Deus. São Paulo: Paulus, 1994. p. 21s. 


\section{O descompasso entre religião e libertação}

O elemento antropológico evidencia-se ainda mais quando se percebe que pelos mesmos motivos que se concluiria que a violência não é inerente à religião, atitudes de libertação também não se ligam necessária e constitutivamente a ela. No horizonte de Schillebeeckx, toda experiência de libertação deve ser vista como humana, mesmo antes de ser encampada pela religião. Na perspectiva do teólogo dominicano, o sentido religioso é sempre posterior ao sentido humano, o que significa que falar muito cedo sobre Deus, à revelia do devido lastro humano e histórico, pode suscitar um discurso que se construa sobre uma imagem envelhecida de Deus. Para ele, a revelação toma como base a realização humana significativa, já que para ele todo acontecimento que opere a libertação dos seres humanos, onde quer que tenha lugar, já é humanamente relevante, ainda que não faça referência direta a Deus. ${ }^{42}$

Que implicações para a relação entre religião e libertação as teses do teólogo belga sugerem? Tem-se que tanto a violência-opressão como a não violência-libertação dizem respeito a experiências antropológicas que precedem o sentido religioso. Então se, por um lado, é preciso superar a tese de que a religião é essencialmente violenta, postura advogada, sobretudo, por visões ateístas do mundo, por outro, é preciso criticar também as afirmações que atrelam à religião a não violência ou projetos de libertação em qualquer nível. Se isso é verdade, determinados eventos históricos mereceriam ser repensados à luz dessa radicalidade antropológica. Por exemplo, o crescente processo de descristianização, na esfera institucional, sentido pela Europa atualmente! Tal arrefecimento do cristianismo institucionalizado está acontecendo, inclusive, em antigos berços de vertentes do protestantismo como, por exemplo, o caso do declínio do metodismo na Inglaterra. É desnecessário mostrar o quão preocupante tem sido esse fenômeno para a maioria dos movimentos que representam o cristianismo ocidental. Normalmente tal preocupação se materializa na articulação de estratégias para mudar o quadro aterrador, afinal, esse declínio é compreendido como algo que deve ser urgentemente corrigido. ${ }^{43}$ Muitos movimentos missionários da atualidade partem do pressuposto de que a Europa, outrora exportadora de missionários ao Sul Global, agora deveria ser novamente evangelizada.

Mas não podemos nos esquivar de fazer determinadas perguntas, por mais desafiadoras que sejam. Eis algumas delas: o critério para se aferir o avanço dos direitos humanos e de justiça no mundo, incluindo a Europa, deveria ser o crescimento e expansão do cristianismo? O cristianismo tem o monopólio da libertação? Há alguma experiência na qual seres humanos sejam libertos para a verdadeira humanidade que não venha da religião? O cristianismo ainda se justifica em histórias de sofrimento e opressão? Essas são algumas das perguntas que são necessárias enfrentar, caso se

42 Cf. SCHILLEBEECKX, 1994, p. 24.

43 Essa tem sido a preocupação, especialmente, dos grupos evangelicais e pentecostais focados em projetos missionários, como aqueles ligados ao movimento de Lausanne. Um exemplo disso pode ser conferido num artigo de Samuel Escobar. Ver ESCOBAR, Samuel. A Europa em Três Tempos. Disponível em: $<$ https://www.ultimato.com.br/revista/artigos/337/capa>. Acesso em: 02 abr. 2019. 
assuma o pressuposto de que tanto a violência como a não violência precedem a religião, ainda que possam ser chanceladas por ela. De modo geral, é preciso investigar se o processo de descristianização institucional da Europa também acompanha processos de degradação humana ou se, ao contrário, as sociedades europeias têm experimentado pari passu ao declínio do cristianismo níveis de humanização, justiça social ou valorização dos direitos humanos cada vez maiores. Se esse for o caso, então somos convidados a sondar vestígios de libertação em meio ao mar de secularização, partindo do pressuposto de que tal libertação não se encontra atrelada à religião, mesmo quando se trata do cristianismo.

O fenômeno de descristianização na Europa pode ser o início de um novo capítulo na história ocidental e, enquanto história profana, pode ser relida de forma nova e criativa por pessoas que creem em Deus. Mas não devemos ignorar que a percepção experiencial que engendra a fé em Deus parte de uma base que se sustenta na contingência do mundo e da história. A linguagem religiosa e sua espiritualidade própria são nutridas pela experiência da limitação humana criatural. Como em Jesus, somos convidados a interpretar os eventos humanos libertadores como meios através dos quais é possível reconhecer o rosto de Deus, afinal, desde que seja libertadora dos seres humanos para uma humanidade melhor e para uma profunda atenção de uns aos outros, a história humana se apresenta aos cristãos como história da salvação de Deus. Como diria Schillebeeckx, o "sentido religioso" torna-se incredível sem o "sentido humano". ${ }^{44} \mathrm{O}$ arrefecimento do cristianismo na Europa nos possibilita compreender que a salvação-vinda-de-Deus não se deve reduzir aos lugares especiais de salvação aos quais chamamos de religiões. A história da salvação, portanto, não se reduz à história das religiões, do judaísmo ou do cristianismo.

\section{Considerações finais}

A apressada relação feita entre religião e violência encontra no essencialismo seu fundamento filosófico. Ora, de fato, uma religião entendida em termos essencialistas se expressa, frequentemente, de forma violenta na medida em que se autodefine como padrão de verdade, eliminando, assim, toda e qualquer possibilidade de reconhecimento do outro e de diálogo tolerante com o diferente. Se as afirmações acerca do Absoluto se confundem com a realidade, se os limites da linguagem não são reconhecidos em sua capacidade de descrever a coisa-em-si, se meras descrições e interpretações se embaralham com a verdade-em-si, se as fronteiras impostas pelos processos histórico-culturais não são percebidas na tentativa de descrição da realidade, a violência, conceitual e prática, será a forma privilegiada de expressão de tal religião.

Contudo, o artigo procurou mostrar os vínculos histórico-culturais e mesmo genéticos da violência. Esta, portanto, não deveria ser vista como essência substancial da religião, ou seja, a religião não pode ser identificada como a matriz sobre a qual germinam as pulsões violentas que avançam sobre as sociedades. Antes, as causas e

${ }^{44}$ Cf. SCHILLEBEECKX, 1994, p. 25-26. 
origens da violência devem ser encontradas na própria sociedade - e seus processos históricos - que a gera e, ao mesmo tempo, busca controlá-la, numa espécie de jogo perigoso que pretende instrumentalizar a violência como meio de controle social.

Assim, a relação entre religião e violência deve ser vista em termos de mediação sociocultural, e não em termos essencialistas. $\mathrm{O}$ que caracterizará uma religião como violenta ou não será, exatamente, a mediação sociocultural da qual aquela lançará mão. Sendo assim, a libertação também deve ser entendida em suas origens antropológicas e sociais e, só num segundo momento, podendo ser identificada também em expressões religiosas, mas não necessariamente. De qualquer forma, ainda que por uma questão de simetria e coerência hermenêutica devamos afirmar a libertação como independente das religiões, mesmo do cristianismo, é possível e desejável que nós pessoas cristãs enxerguemos nos processos histórico-sociais de humanização a face do Cristo que deseja a libertação de todos e todas.

\section{Referências}

ANÔNIMO. A Epopeia de Gilgamesh. São Paulo: Martins Fontes, 2011.

ARENDT, Hanna. Sobre a violência. Rio de Janeiro: Relume Dumará, 2001.

ARISTÓTELES. Metafísica. Tradução Joaquim Dornelles. Madri: Gredos, 1987.

ARMSTRONG, Karen. Campos de sangue: religião e a história da violência. São Paulo: Companhia das Letras, 2016.

AVALOS, H. Fighting Words: the origins of religious violence. Amherst, NY: Prometheus Books, 2005.

BRAMBILLA, Franco Giulio. Edward Schillebeeckx. São Paulo: Loyola, 2006.

DAWKINS, Richard. Deus, um delírio. São Paulo: Cia das Letras, 2007.

ESCOBAR, Samuel. A Europa em Três Tempos. Disponível em: <https://www.ultimato.com. $\mathrm{br} /$ revista/artigos/337/capa $>$.

FORNERO, Giovanni. Essencialismo. In: ABBAGNANO, Nicola (Org.). Dicionário de Filosofia. São Paulo: Martins Fontes, 2007.

GIBELLINI, Rosino. A teologia do século XX. São Paulo: Loyola, 2002.

GILBERT, Paul. The compassion mind: a new approach to life's challenges. Londres: Constable, 2009.

GIRARD, René. A rota antiga dos homens perversos. São Paulo: Paulus, 2009.

. A violência e o sagrado. São Paulo: Paz e Terra, 1990.

. Eu via Satanás cair como um relâmpago. São Paulo: Paz e Terra, 2012.

O bode expiatório. São Paulo: Paulus, 2004.

O sacrificio. São Paulo: É Realizações, 2011.

GIRARD, René; VATTIMO, Gianni. Cristianismo e relativismo: verdade ou fé frágil? Aparecida: Santuário, 2010.

GRACIA, Tomas Ibañez. O giro linguístico. In: IÑIGUEZ, Lupicinio (Coord.). Manual de Análise do Discurso em Ciências Sociais. 2. ed. Petrópolis: Vozes, 2005.

HABERMAS, Jürgen. El discurso filosófico de la modernidad. Madri: Taurus, 1989.

HALL, John R. Religion and Violence: social processes in comparative perspective. In: DILLON, Michele (Ed.). Handbook for the Sociology of Religion. Cambridge University Press, 2003. HENRY, Michel. Encarnação: uma filosofia da carne. São Paulo: É Realizações, 2013.

HITCHENS, Christopher. God is Not Great: how religion poisons everything. First Trade Edition, [S.1.]: Atlantic Books, 2007. 
KIMBALL, C. When religion becomes evil: five warning signs. New York: Harper Collins, 2008. LOSURDO, Domenico. A não violência: uma história fora do mito. Rio de Janeiro: Revan, 2012. MOINGT, Joseph. Deus que vem ao homem: do luto à revelação de Deus. São Paulo: Loyola, 2010. v. 1.

RELIGULOUS. Dirigido por Larry Charles; Produção de Bill Maher, Jonah Smith, Palmer West. Apresentação de Bill Maher. Estados Unidos da América: Thousand Words, 2008.

ROCHA, Abdruschin Schaeffer. O Deus que vem a nós: reflexões hermenêutico-teológicas da revelação desde cima e desde baixo. Horizonte, Belo Horizonte, v. 15, n. 47, p. 974-996, jul./ set. 2017.

ROCHA, Abdruschin Schaeffer; OLIVEIRA, David Mesquiati de. Teologia da missão e violência: Superar a violência interna e agir energicamente contra a injustiça. Pistis e Praxis, Curitiba, v. 10, n. 1, p. 144-166, jan./abr. 2018.

SACCHETTO, Mauro. Essência. In: ABBAGNANO, Nicola (Org.). Dicionário de Filosofia. São Paulo: Martins Fontes, 2007.

SCHILLEBEECKX, Edward. Cristo y los cristianos: gracia y liberación. Madrid: Cristiandad, 1982.

História humana: revelação de Deus. São Paulo: Paulus, 1994.

Religião e violência. Concilium, Petrópolis, v. 272, n. 4, p. 168-185, 1997.

THE ROOT OF ALL EVIL? Dirigido por Russell Barnes. Produzido por Alan Clements. Inglaterra: Channel 3, 2006.

VATTIMO, Gianni. Creer que se cree. Buenos Aires: Paidós, 1996.

. La sociedade transparente. Barcelona: Paidós Ibérica, 1990. 